\title{
Suggestions for the Effective Intraoperative Neurophysiological Monitoring in Microvascular Decompression Surgery of Hemifacial Spasm
}

Sung-Hyuk Lim

Department of Neurology, Samsung Medical Center, Seoul 06351, Korea

\section{편측성 안면경련 환자의 미세혈관 감압수술에서 효과적인 수술 중 신경계 감시검사를 위한 제안}

임성혁

삼성서울병원 신경과

Hemifacial spasm is a disease caused by involuntary facial muscles with repeated unilateral convulsive spasms. It involves contraction of multiple muscles at the same time (synkinesia). The pathogenesis appears to be the pressure on the vessel by the facial nerve. This study included hemifacial spasm patients, who received microvascular decompression surgery. Brainstem auditory evoked potential and the examination time were carefully noted when using brain surgical retractor. The facial nerve electromyography tests for the identification of artifacts and EMG waveform when the facial nerve damage, about the importance of the maintenance of anesthesia in the lateral spread response and in a somatosensory evoked potential propose a new method. Based on the above test, it will be more effective.

Key words: Hemifacial spasm, Brainstem auditory evoked potentials, Electromyography, Lateral spread response, Somatosensory evoked potentials

This is an Open Access article distributed under the terms of the Creative Commons Attribution Non-Commercial License (http://creativecommons.org/licenses/by-nc/4.0) which permits unrestricted non-commercial use, distribution, and reproduction in any medium, provided the original work is properly cited.

Copyright @ 2016 The Korean Society for Clinical Laboratory Science. All rights reserved.

Corresponding author: Sung-Hyuk Lim Department of Neurology, Samsung Medical Center, 81 Irwon-ro, Gangnam-gu, Seoul 06351, Korea

Tel: 82-2-3410-2737

Fax: 82-2-3410-2759

E-mail: shlim1113@naver.com

Received: June 23, 2016 Revised 1 $1^{\text {st: }}$ July 7, 2016 Revised $2^{\text {nd }}:$ August 5, 2016 Revised $3^{\text {rd: }}$ : August 5, 2016 Accepted: August 5, 2016

\section{서 론}

편측성안면연축(hemifacial spasm, HFS)의 발병원인은 안면 신경이 혈관에 의해 압박을 받아서 나타나게 되며 이러한 혈관의 압박은 혈관 내 죽상경화성 변화에 의해 기인 하는 것으로 사료되 고 일반적으로 유년층이나 청장년층 보다 노년층에서 발병률이 높 다[1,2]. 이런 안면 경련의 증상은 점차 진행성으로 발전해서 심한 경우 안면마비나 안면 비대칭 까지 초래할 수 있다. 병원에 내원하 는 환자들은 흔히 한방치료나 보톡스와 같은 약물 치료를 받는 경
우가 많은데 이런 치료와 시술은 일시적으로 증상을 약간 완화시켜 주기는 하나 영구적으로 치료를 할 수 없기 때문에 외과적 수술에 의한 치료법이 가장 효과적이고 보편적으로 시행되고 있다[3]. 안 면경련 환자에 있어서 수술 중 신경계감시 검사(intraoperative neurophysiological monitoring, IONM, INM)는 현재 환자의 안 면신경 또는 청신경의 보존을 위해 유용하게 사용되고 있으며 시행 하는 검사의 종류로는 청각 유발전위검사(brainstem auditory evoked potentials, BAEP), 안면신경 근전도검사(facial nerve electromyography), 측면전파반응(lateral spread response, 
LSR), 체성감각 유발전위(somatosensory evoked potentials, SSEP)방법이 있고 위의 검사방법들은 모두 수술 중에 이뤄지며 단 시간에 많은 검사를 동시에 진행해야 하고 수술실의 여러 환경들에 서 발생하는 잡파(artifact)들이 배제된 정확한 데이터를 추출해야 만 한다. 원활한 검사를 위해 검사자가 수술이 진행되는 과정과 검 사에 대해 정확히 알고 있어야 환자와 의사에게 도움을 줄 수 있다. 본 연구는 여러 종류의 수술 중 신경계 감시 검사들이 실제 수술을 하는 과정에서 어떻게 적용 되는지 자세히 알아보고 가장 원활한 검사법에 대해 제안하고자 한다[4,5].

\section{재료 및 방법}

\section{1. 검사대상}

본 연구에 이용된 자료들은 환자들이 작성한 수술 동의서를 토 대로 수술 중 진행된 검사들의 데이터를 근거로 작성되었으며 2015년 1월부터 2016년4월까지 삼성서울병원에서 미세혈관감 압술(microvascular decompression, MVD)을 받는 환자 418명 을 대상으로 하였다. 이 중 2016년 3월부터 4월까지 13명의 환자 에서는 본 저자가 제안한 방법으로 체성감각 유발전위 검사를 진행 하였다. 기존의 2채널 검사에서는 상지와 하지의 구분 없이 $\mathrm{Cz}-\mathrm{FPz}$ 의 피질전위(cortical potential), $\mathrm{FPz}-\mathrm{C} 5 \mathrm{~s}$ 의 피질하 전 위(subcortical potential) 채널로 검사를 진행하였으나 본 연구에 서는 상지의 검사는 Erb's point-FPz 의 상완신경총전위(brachial plexus potential), $\mathrm{C}_{5} \mathrm{~s}-\mathrm{FPz}$ 의 피질하 전위, $\mathrm{C}^{\prime}$ 와 $\mathrm{C} 4^{\prime}-\mathrm{FPz}$ 의 피 질전위, 하지에서는 $\mathrm{C} 5 \mathrm{~s}-\mathrm{FPz}$ 의 피질하 전위, $\mathrm{Cz}-\mathrm{FPz}$ 의 피질전 위 채널로 검사하였고 연구에 시도된 검사는 신경과 및 신경외과 담당 주치의들과의 협의를 통해 진행되었다[6,7].

\section{2. 검사장비}

신경계 추적감시 검사기기는 Xltek Protektor 32 IOM (Natus medical Inc., Oakville, Canada)을 사용하였다. 청각유발전위검 사는 대역폭(range) $\pm 250 \mu \mathrm{V}$, 차단역치(reject threshold) \pm 40 $\mu \mathrm{V}$, 저주파 필터(low frequency filter, LFF)/고주파 필터(high frequency filter, HFF) $150 \mathrm{~Hz} / 3 \mathrm{kHz}$, 시간축(timebase) 1.5 $\mathrm{ms} / \mathrm{div}$ 으로, 근전도검사(electromyography, $\mathrm{EMG})$ 는 대역폭 $\pm 50 \mathrm{mV}$, 차단역치 $\pm 15 \mathrm{mV}$, 저주파 필터/고주파 필터 $10 \mathrm{~Hz} / 3$ $\mathrm{kHz}$, 시간축 $100 \mathrm{~ms} / \mathrm{div}$, 측면전파반응은 대역폭 $\pm 50 \mathrm{mV}$, 차단 역치 $\pm 15 \mathrm{mV}$, 저주파 필터/고주파 필터 $10 \mathrm{~Hz} / 3 \mathrm{kHz}$, 시간축 10 $\mathrm{ms} / \mathrm{div}$, 체성감각유발전위검사는 대역폭 $\pm 250 \mu \mathrm{V}$, 차단역치 $\pm 80 \mu \mathrm{V}$, 저주파 필터/고주파 필터 $30 \mathrm{~Hz} / 200 \mathrm{~Hz}$, 시간축 10 $\mathrm{ms} / \mathrm{div}$ 으로 설정하여 검사를 진행하였다(Table 1).

\section{3. 검사방법}

1) 청각유발전위(brainstem auditory evoked potentials, BAEP)

소리자극(click sound)이 청신경과 뇌간을 거쳐 측두엽으로 전 달되는 청각경로에서 청각유발전위 파형이 측정된다. 환자의 양쪽 귓볼 $(\mathrm{A} 1, \mathrm{~A} 2)$ 를 활동전극으로 하고 두정부 $(\mathrm{Cz})$ 에 기준전극을 설치 하고 교환전위(alternating polarity)로 $120 \mathrm{~dB}$ SPL (decibel sound pressure level) 또는 $90 \mathrm{~dB} \mathrm{nHL}$ (normal hearing level)의 세기로 자극하고 반대편은 $80 \mathrm{~dB}$ 의 차폐음(white noise)을 흘려 보내 소리자극을 차단하였다. 국제 기준에 따르면 $1 \mathrm{kHz}$ 의 가청 주 파수를 이용해 5 12 Hz의 빈도로 500 1000회 자극했을 때 가장 좋은 파형을 얻을 수 있다고 제시했다[6]. 하지만 수술 중 수초 내에 손상 받을 수 있는 청각신경의 보존과 빠른 검사결과를 얻기 위해 $43.90 \mathrm{~Hz}$ 의 자극으로 400 회 자극빈도를 준 후 10 초 이내에 평균화 과정(average)으로 기록된 파형을 분석했다. 제 $\mathrm{V}$ 파형의 잠복기가 $1 \mathrm{~ms}$ 이상 연장되거나진폭이 $50 \%$ 이상 감소하면 의사에게 즉시 알 려 조치를 취할 수 있도록 하고 파형이 회복되기까지 기다린 후 다 시 수술을 진행하였다[8,9,16].

\section{2) 근전도(electromyography, EMG)}

미세혈관감압 수술에서 근전도검사는 안면신경 지배를 받는 근 육에 침전극(subdermal needle electrode)을 이용하여 안면근육 인 전두근(frontalis), 안륜근(orbicularis oculi), 구륜근(orbicularis oris), 턱근(mentalis)에 삽입하고자유진행근전도 방법(spontaneous EMG or free-running EMG)으로 수술이 진행되는 동안 지속적으 로 관찰하였다(Fig. 1).

Table 1. Filter setting

\begin{tabular}{lccccc}
\hline & Input range & Reject range & LFF & HFF & Timebase (ms/div) \\
\hline BAEP & $\pm 250 \mu \mathrm{v}$ & $\pm 40 \mu \mathrm{v}$ & $150 \mathrm{~Hz}$ & $3 \mathrm{kHz}$ & 1.5 \\
EMG & $\pm 50 \mathrm{mv}$ & $\pm 15 \mathrm{mv}$ & $10 \mathrm{~Hz}$ & $3 \mathrm{kHz}$ & 100 \\
LSR & $\pm 50 \mathrm{mv}$ & $\pm 15 \mathrm{mv}$ & $10 \mathrm{~Hz}$ & $3 \mathrm{kHz}$ & 10 \\
SEP & $\pm 250 \mu \mathrm{v}$ & $\pm 80 \mu \mathrm{v}$ & $30 \mathrm{~Hz}$ & $200 \mathrm{~Hz}$ & 10 \\
\hline
\end{tabular}

Abbreviation: LFF, low frequency filter; HFF, high frequency filter; BAEP, brainstem auditory evoked potentials; EMG, Electromyography; LSR, lateral spread response SEP, somatosensory evoked potentials. 
3) 측면전파반응(lateral spread response, LSR)

측면전파반응은 근전도검사를 시행하는 안면근육에서 시행하 며 단일자극에 의해 나타나는 반응이다. 안면 신경의 상악분지 (zygomatic branch)와 하악분지(buccal branch)의 신경분지에 각각 전기적 자극을 가했을 때 나타나는 반응을 기록하는 방법으로 자극의 지속시간(duration) $0.1 \sim 0.3 \mathrm{~ms}$, 자극세기(stimulation intensity) 0 30 mA으로 파형이 측정되는 역치(threshold)에서 20 30\%를 더 강하게 자극하는 최대상자극(supramaximal stimulation)방법으로 검사하였다. 신경의 상악분지를 자극 시 하 악분지에서 근육의 수축으로 복합근육활동전위(Compound muscle action potentials, CMAP)가 측정된다(Fig. 2). 하악분지 자극의 경우 이와 반대로 상악분지의 근육에서 복합근육활동전위 가 나타나게 되고 이는 신경의 합선에 의해 나타나는 반응이며 Teflon-felt라는 수술재료를 이용해 혈관과 신경이 감압되면 파형 이 사라지게 되어 수술의 지표로서의 역할을 해준다[10,11] (Fig. 3). 개두술이 진행된 이후에 초기파형(baseline data)을 측정하는 것이 좋고 초기파형(baseline data), 경막절개 전(before dura open), 경막절개 후(after dura open), 감압 전(before decompression), 감압 후(after decompression), 경막봉합 후(dura closed), 피부봉합 후(closing data)로 구간을 나누어 수술이 진행 되는 순서에 따라 반응을 관찰해야 정확한 검사가 될 수 있고 검사 를 판독하는 의사에게 그 당시의 상황을 시간별로 나열해 보여줄 수 있기 때문에 위의 방법으로 검사하였다.

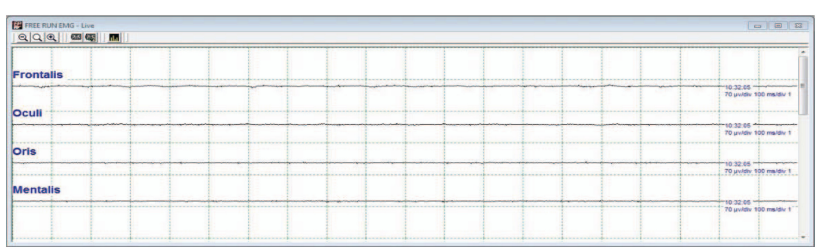

Fig. 1. Free running EMG (stable).
4) 체성감각유발전위(somatosensory evoked potentials, SSEP)

체성감각유발전위 검사는 상지의 정중신경(median nerve)과 하지의 후경골신경(posterior tibial nerve)을 자극한다. 자극방식 은 항전류(constant current)방식으로 15 40 mA의 자극세기로 자극폭은 100 300 $\mu \mathrm{s}$ 로 하고, 자극은 2 8 Hz로 조정하고 250 1000 회 자극빈도를 준 후 평균화된 파형을 분석하는 것이 일반적
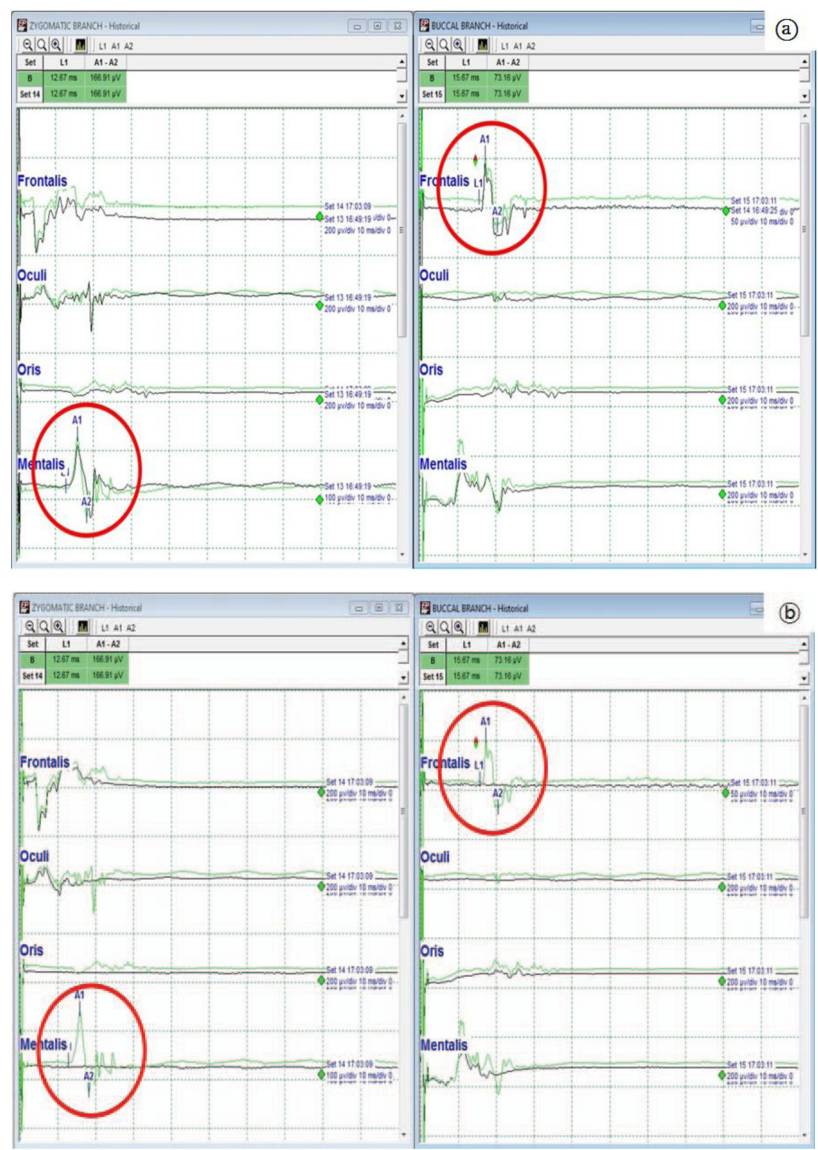

Fig. 2. Before decompression lateral spread response zygomatic branch and buccal branch stimulation. (a) disappeared lateral spread response after decompression (b).

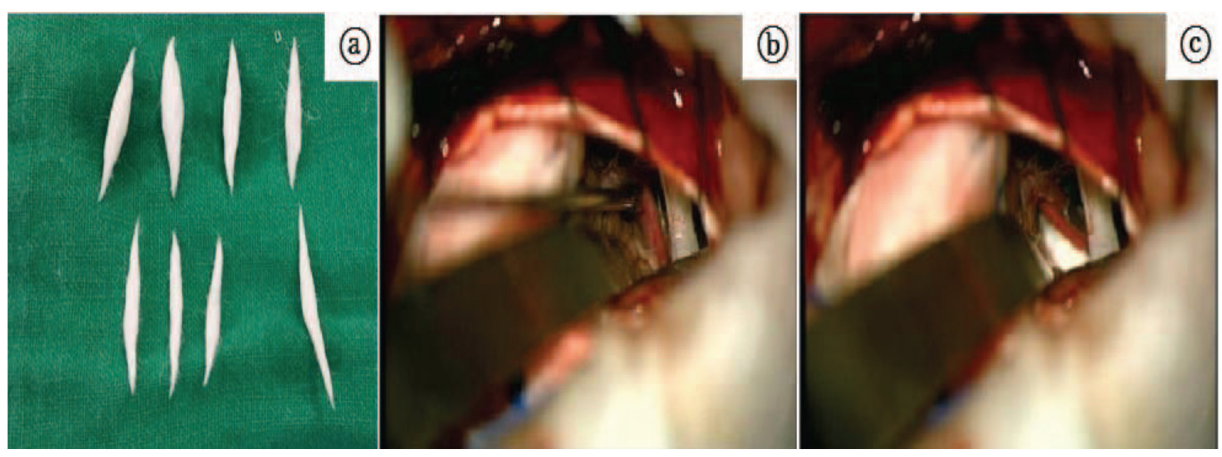

www.kjcls.org
Fig. 3. Teflon-felt is insert between the facial nerve and blood vessel (a). Before decompression (b) and after decompression (c). 
이지만 수술실의 불규칙하고 잡파가 혼입되기 쉬운 환경 때문에 자 극빈도를 $2.38 \mathrm{~Hz}$ 로 하고, 상지에서의 자극은 $15 \mathrm{~mA}$, 하지의 자극 은 $20 \mathrm{~mA}$ 로 활동전극은 피질하 전위 C5s (Cervical 5 level)와 대 뇌피질 전위인 $\mathrm{Cz}^{\prime}$ 에서 $\mathrm{FPz}$ 를 기준전극으로 하고 50 회 자극에 의 해 평균화된 파형을 분석한다. 진폭이 $50 \%$ 이상 감소하거나 절대잠 복기가 10\%이상 연장되면 경고를 한다(Fig. 4). 8채널로 수술 중 감 시검사를 하던 이전의 신경감시 검사에서는 체성감각유발전위 검 사의 채널이 부족해 자세한 검사를 할 수 없었지만 최근 검사장비 의 발달로 인해 검사 가능 채널수가 8 채널에서 32 채널로 증가하여 채널의 추가가 가능해졌고 수술 자세로 인한 신경의 눌림과 수술 부위의 뇌기능을 자세히 평가 할 수 있도록 상지에서는 Erb's point 의 N9 파형을 관찰해 상완신경총(brachial plexus)의 손상을 감지 하고 C3'과 C4'에서 N20의 피질전위를 검사하였다(Fig. 5) [12].

\section{결 과}

청각유발전위 검사는 검사결과에 대해 10 초 이내에 집도의에게 즉시 알려주어야만 하고 수술 중에 가장 변화가 심한 검사이기에 검사를 중점 적으로 봐야 하는 감압 전부터 경막(dura matter)을 닫 는 시점까지는 검사를 최대한 빨리 그리고 많은 횟수를 시행해야 수술에 도움을 줄수 있다 $[13,14]$. 주의할 점은 수술도구로 사용하 는 견인기(Retractor)로 인해 소뇌와 청신경 및 이하 뇌의 구조물이 눌리는 현상에 의해 일시적인 청신경의 손상으로 청각유발전위 파 형이 감소될 수 있으므로 집도의는 파형이 정상이더라도 수시로 견 인기를 풀어주는 과정을 반복하며 수술할 것을 추천한다[15]. 이때 검사자는 견인기를 조이고 푸는 과정에서 청신경의 손상유무를 제 대로 알 수 없다. 왜냐하면 견인이 되고 있거나 견인을 푸는 과정에 서 약 5 10초 정도의 시간이 소요되고 이 과정에서의 검사는 신경 이 손상을 이미 받은 상태이거나 그 이전의 상태이므로 평균화가 시작되고 파형이 만들어지는 시점의 차이로 인해 검사의 위양성과
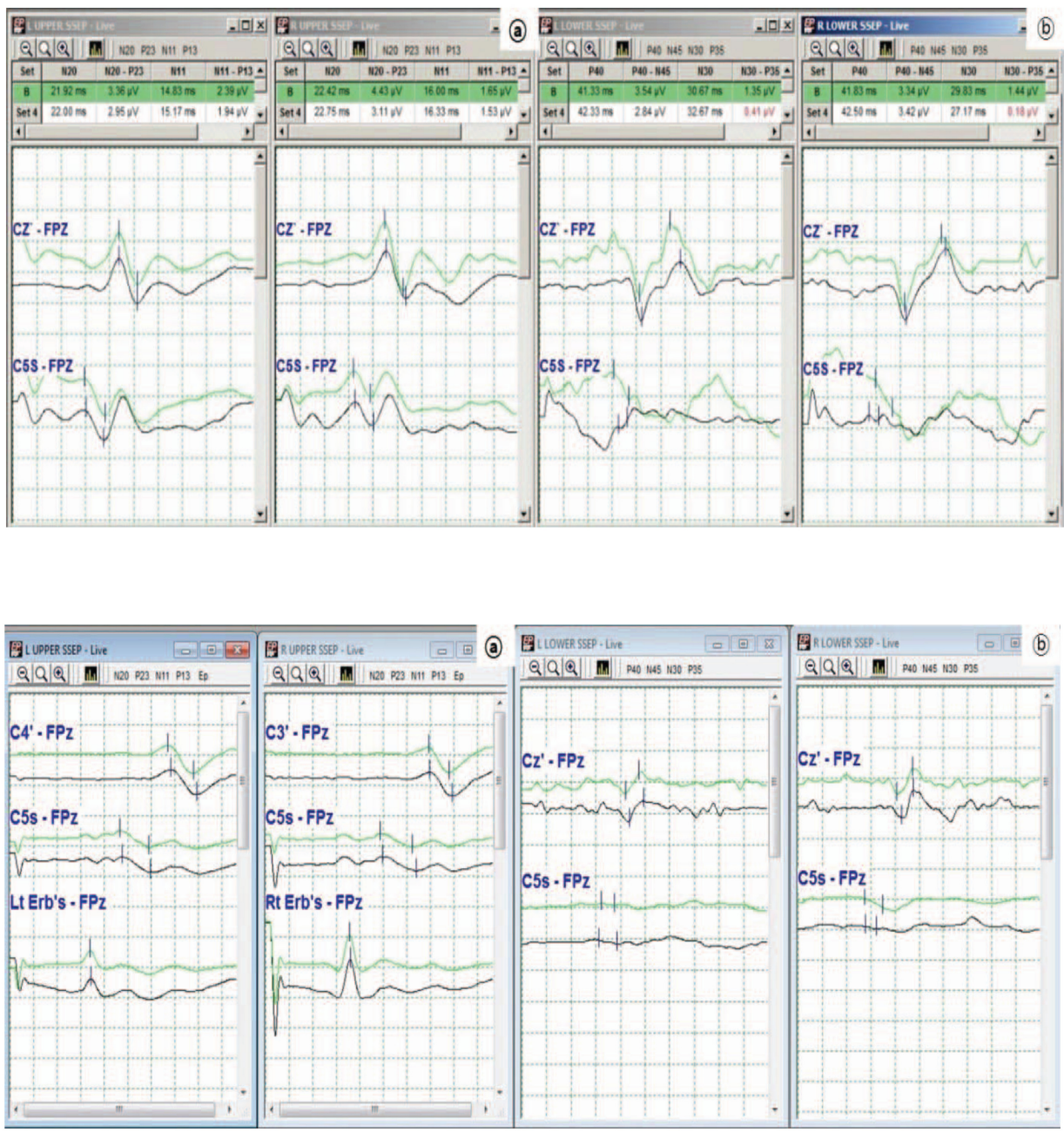

Fig. 4. SSEP 2ch Upper Cz' cortial potentials (N20), C5s subcortical potentials (N11) (a) and Lower Cz' cortical potentials (P40), C5s subcortical potentials (N30) (b).

Fig. 5. Modified ssep Upper Erb' point brachial plexus potentials (N9), C5s subcortical potentials (N11), C3' and C4' cortical potentials (N20)waveform (a) and Lower Cz' cortical potentials (P40), C5s subcortical potentials (N30) waveform (b). 
위음성이 서로 혼재하는 상태로 검사로서의 가치가 떨어지기 때문 이다. 그러므로 검사자는 견인기가 완전히 결착되거나 완전히 풀려 있는 상태에서 지속적으로 검사를 해야 정확한 데이터를 얻을 수 있다. 청각유발전위 검사는 최근에 개발된 디지털 장비 중에 아날 로그 디지털 변환(analog digital conversion)의 샘플링 레이트 (sampling rate)의 제약이 거의 없고 잡파의 혼입이 없는 환경에서 청각유발전위 파형이 형성되는 횟수는 보통 100 200회(약 5초) 내에 파형으로 식별 할 수 있을 정도로 나타나게 된다(Fig. 6). 만일 파형의 형성이 5 초 이내에 형성되지 않는다면 제일먼저 잡파의 혼 입을 의심해보고 장비에 내장되어있는 스피커로 전류의 혼입여부 를 확인한 뒤 이를 제거해야 한다. 검사가 진행되는 10 초 이내에 초 기파형과 같은 진폭의 파형 형성이 잘 된다면 평균화가 끝나는 10 초까지 기다리지 말고 다시 한번 검사를 진행하는 것도 좋은 방법 이 될 수 있다.

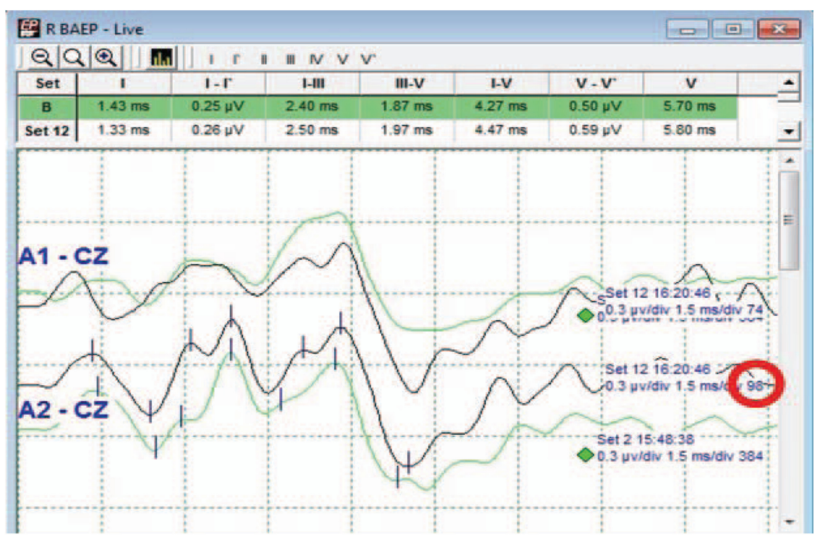

Fig. 6. 100 trials of repetition to be averaged BAEP waveform.
미세혈관 감압 수술 시 근전도 검사에서 대부분의 경우 직접신 경을 자극해서 안면신경을 확인하는 경우(triggerd $\mathrm{EMG}$, direct nerve stimulation)는 거의 드물고 수술 중 혈관과 신경을 감압하 는 과정에서 전체적이거나 부분적인 긴장성 변화(tonic activity) 들이 나타난다. 이런 경우에 즉시 집도의에게 알려 안면신경에 지 속적인 손상을 받지 않도록 한다. 또한 근전도 검사에서는 긴장성 변화와 위상성 변화를 감별하기 위해서 파형을 정확히 분석해야 하 는데 이때 외래 근전도실에서 시행되는 침근전도검사 처럼 안면신 경 근전도검사의 각 채널에 사운드가 들어가도록 설정하면 잡파와 신경손상 시 나타나는 파형의 감별이 수월하다(Fig. 7).

측면전파반응은 수술 중에 경막을 절개한 후 뇌척수액이 누출이 되고 누출되는 양상에 따라 안면신경을 감압하기 전에 측면전파반 응이 사라지는 경우가 다수발생하며 반응이 사라지는 양상에 따라 서 집도의가 신경과 혈관을 감압하는 범위를 조정하기 때문에 측면 전파반응이 사라지는 시점이 중요하다. 또한 실제로 마취 이후에 검사준비를 마치는데 까지 약 25 30분 정도 소요가 되는데 간혹 검사준비가 끝난 이후즉시 검사했을 때 측면전파반응이 나타나는 환자들이 있다. 하지만 측면 전파반응이 나타난다고 해서 그 즉시 초기파형을 측정해 기준으로 삼으면 안 된다. 마취가 서서히 풀리 고 사연속자극 검사(train of four)에서 근육의 수축 횟수가 2 번 에 서 혹은 3 번인 상태를 지속적으로 일정하게 유지된 상태에서 검사 를 해야 한다.

체성감각유발전위검사는 출혈이나 허혈 발생시 발견이 용이하 고 체온이나 혈압도 검사에 영향을 줄수 있다. 수술이 끝난 후 환자 들 중에 간혹 팔 저림증이 발생하는 경우가 있다. 수술을 할 때 환자 는 파크벤치(park bench)라는 수술 자세로 수술을 받게 된다. 이런 환자들은 수술 자세로 인해 나타나는 액와(axilla)부위의 상완신경
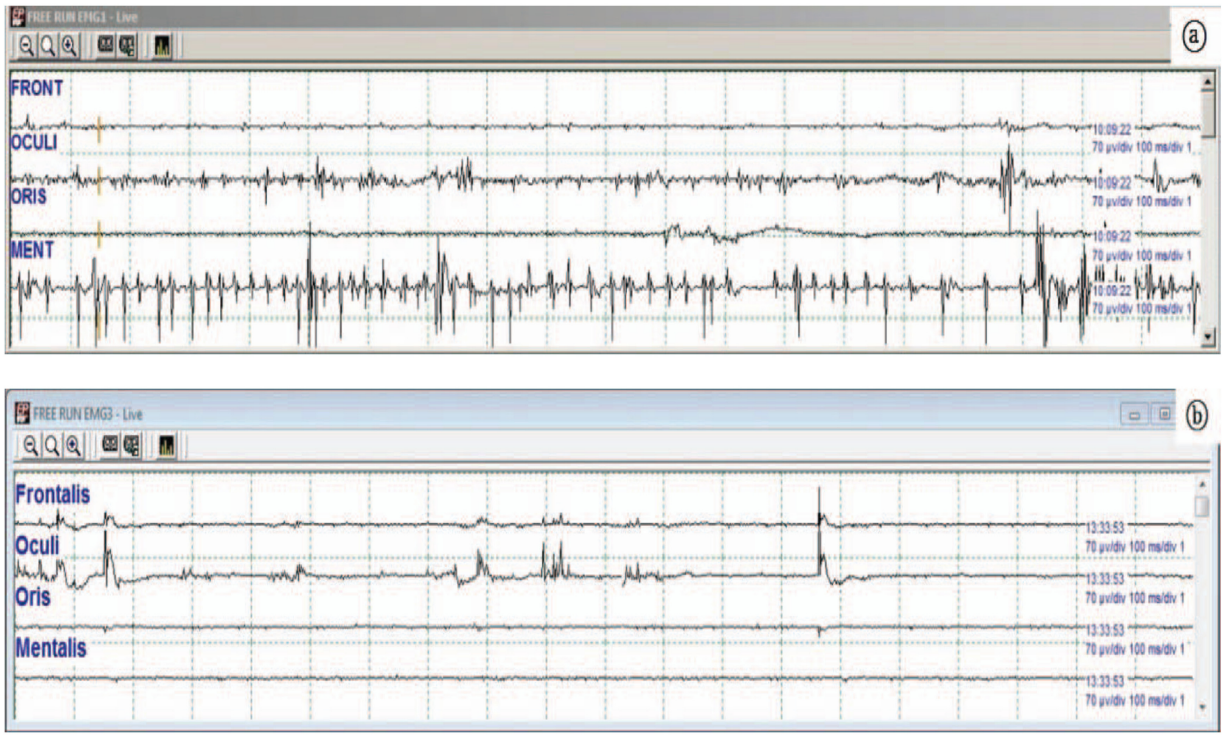

Fig. 7. Tonic activity (tonic discharge) make that damaged facial nerve (a) and phasic activity is artifact of facial electromyography (b). 

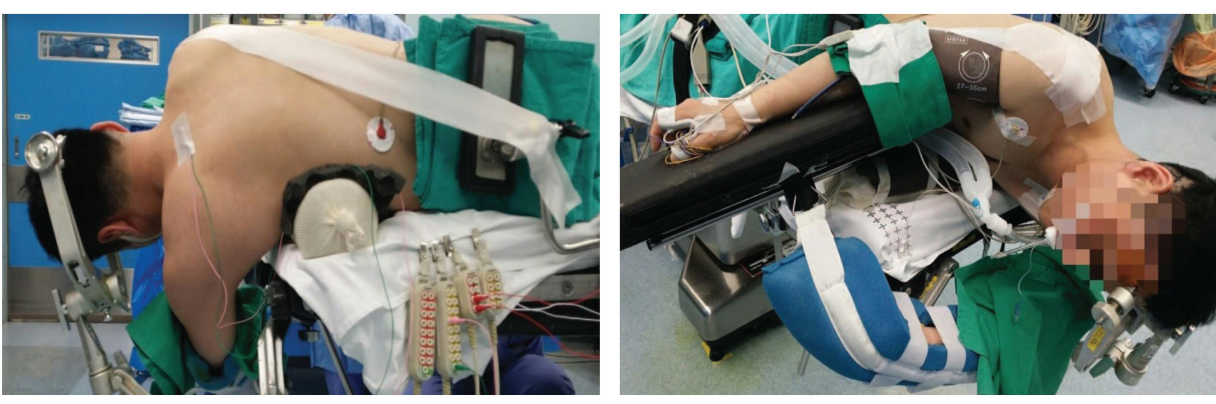

Fig. 8. Surgical position (park bench).

총의 눌림에 의해 나타날 가능성이 높다(Fig. 8).

\section{고 찰}

청각유발전위검사에서 가장 주의할 점은 각각의 수술 방 마다 사용하는 장비나 전력의 시스템에 따라 전기적인 잡파의 혼입이 심 해 검사의 어려움이 있을 수 있는데 이런 경우에는 잡파의 제거가 우선시 되어야 한다. 가장 빈번한 예로 근전도검사에서 잡파가 혼 입되는 경우 이 부분을 해결하지 못하면 청각유발전위 검사도 정확 하게 검사를 할 수 없게 된다. 그 이유는 근전도 검사는 $70 \mu \mathrm{V}$ 로 검 사하고 청각유발전위 검사는 이보다 훨씬 작은 전위인 $0.2 \mu \mathrm{V}$ 로 검사를 진행하기 때문에 더 큰 전위를 보는 근전도 검사에서 검사 가 원활하게 되지 않는다면 이보다 100 배 이상 작은 전위를 측정하 는 검사는 당연히 검사가 되지 않는 것이다. 또한 현재 임상에서 사 용하고 있는 장비들의 각 제조사에 따라 각 장비의 샘플링 레이트 가 다르기 때문에 파형의 구현이 원활하지 않은 경우가 있어 장비 가 갖는 최적의 자극빈도수를 검사자가 직접 조절하여 검사하는 것 이 가장 바람직하다[17].

근전도검사에서 긴장성 변화시 나타나는 파형의 특징은 일정한 간격의 지속적인 파형이 유지되고 이에 따른 사운드도 일정하게 나 타나지만 위상성 변화의 경우는 뇌의 견인기나 소작기(bovie)에 의 한 변화들이 빈번하고 이는 파형의 동기성이나 역위상은 같지만 긴 장성 변화의 일정하고 규칙적인 소리와는 다르게 단일자극에 의해 연속적이지 않고 불규칙한 소리가 나타나는 점이 긴장성 변화와다 른 점이다.

측면전파반응은 마취가 시작된 초기에 다량의 마취제와 근이완 제가 투여되고 근이완제의 영향으로 인해 마취 직후 측면전파반응 이 측정되지 않는 경우가 많다. 마취의 심도가 시간이 지남에 따라 서서히 약해지면 파형을 관찰할 수 있게 된다. 가장 중요한 점은 파 형이 관찰되고 초기 파형을 측정한 후 그만큼의 재현성있는 파형을 측정할 수 있을만한 마취심도를 잘 유지하는 것이다. 마취의 심도 가 너무 얕아지면 신경과 혈관의 감압이 충분히 되었음에도 불구하 고 초기파형의 측정에 사용되었던 최대상자극의 세기보다 더 약한
자극에서 측면전파반응이 측정될 수 있기 때문에 검사결과를 신뢰 할 수 없게 된다. 그래서 사연속자극검사에서 근육이 수축되는 횟 수가 일정하게 유지되는 조건에서 수술을 진행해야 신뢰할 만한 검 사 결과를 얻을 수 있다.

체성감각유발전위 검사에서 상지는 C3', C4', C5s, Erb's point 의 4 채널로 하지에서는 $\mathrm{Cz}, \mathrm{C} 5 \mathrm{~s}$ 의 2 채널로 총 5 채널로 전극을 추 가로 설치해 검사를 진행하였더니 이전에는 정확하게 측정되지 않 던 C3', C4'의 N20의 피질전위를 정확하게 측정할 수 있었고 Erb's point의 N9전위가 측정되어 상완신경총의 기능도 평가할 수 있게 되어 환자의 상태에 대해 미리 예견할 수 있게 되었다[14].

미세혈관감압술은 유양돌기의 후방에서 개두술을 시행하여 경 막을 개방한 다음 수술용 미세현미경을 이용하여 뇌혈관으로부터 압박을 받고 있는 신경을 박리하고 혈관이 원래의 위치로 돌아가 다시 신경을 압박하는 것을 방지하기 위해 Teflon-felt를 사용해 신 경과 혈관 사이에 넣어 분리시켜준다. 이 과정에서 시행하는 뇌신 경 모니터링은 수초 이내에 빠르게 변하는 파형들과 여러 종류의 검사들을 단시간에 정확하게 수행해야 한다[6]. 발생할 수 있는 후 유장애는 청력장애, 출혈, 두통, 어지러움, 뇌척수액의 누출 등이 있다. 이러한 후유장애를 최소화하고 안전하게 수술을 할 수 있도 록 수술 중에 청각유발전위, 근전도검사, 측면전파반응을 동시에 검사하여 검사에 대한 결과를 실시간으로 알려야 하며 빠르고 정확 한 검사를 위해 한 화면에서 모든 검사를 할 수 있도록 검사화면을 구성하고 집도의와함께 수술의 진행 정도를 알기 위해 미세현미경 으로 보는 실시간 화면 또한 함께 공유하길 권장한다. 마지막으로 검사자는 수술 중 파형의 변화가 발생하였을 때 변하는 파형의 변 화가 어디에서 기인한 것인지 잘 알고 대처해야 할 것이다.

\section{요 약}

편측성 안면경련(hemifacial spasm)은 불수의적으로 안면의 근육에서 발작적인 경련이 일측성으로 반복해서 발생하는 질환이 다. 한 근육의 수축으로 인해 동시적으로 여러 근육이 동시에 수축 되는 동시 수축성(synkinesia)이 특징이다. 발병원인은 제 7뇌신경 
인 안면신경이 혈관에 의해 압박을 받아서 나타나게 된다. 본 연구 는 편측성 안면경련 환자의 미세혈관 감압 수술을 받은 환자를 대 상으로 수술 중 진행되는 신경계 감시검사 방법들에 대해 다루었 다. 청각유발전위 검사에서는 수술용 뇌 견인기의 사용시 주의 사 항과 검사시기에 대해 언급하였다. 안면신경의 근전도검사에서는 잡파의 혼입과 신경손상 시 근전도 파형의 감별에 대해, 측면전파 반응 검사에서는 마취의 유지의 중요성에 대해 그리고 체성감각 유 발전위검사에서는 환자를 좀더 자세하게 검사할 수 있도록 새로운 방법을 제안하였다. 위에 언급한 내용들을 토대로 검사한다면 수술 중 신경계 감시 검사를 원활하게 할 수 있으리라 생각된다.

\section{Acknowledgements: None}

Funding: None

Conflict of interest: None

\section{References}

1. Jun SM, Kim JK, Jung JI, Cha JK, Kim SH, et al. Electrophysiologic study for estimating the clinical severity of hemifacial spasm. 1998;2:205-211.

2. Levy EI, Resnick DK, Jannetta PJ, Lovely T, Bissonette DJ. Pediatric hemifacial spasm: the efficacy of microvascular decompression. Pediatric Neurosurgery. 1997;27(5):238-241.

3. Auger RG, Piepgras DG, Laws ER. Hemifacial spasm: results of microvascular decompression of the facial nerve in 54 patients. Mayo Clinic Proceedings. 1986;61(8):640-644.

4. Kakizawa T, Shimizu T, Fukushima T. Monitoring of auditory brainstem response (ABR) during microvascular decompression (MVD): results in 400 cases. No to Shinkei. 1990; 42(10):991-998.

5. Lee SG, Park K, Park IS, Seo DW, Uhm DO, Nam DH, et al. Intraoperative neurophysiologic monitoring and functional outcome in cerebellopontine angle tumor surgery. J Korean
Neurosurg Soc. 2000;29:778-785.

6. Seo DW. Intraoperative neuromonitoring. Korean J Clin Neurophysiol. 2008;10(1):1-12.

7. Park SK, Hyun SC, Lim SH, Park CW, Park JW, et al. Basic techniques of intraoperative neurophysiological monitoring. Korean J Clin Lab Sci. 2013;45(2):77-85.

8. American Clinical Neurophysiology Society. Guideline 11C: Recommended standards for intraoperative monitoring of auditory evoked potentials [cited 2016 June 23]. Available from: https://www.acns.org/pdf/guidelines/Guideline-11C.pdf

9. Park SK, Hyun CH, Lim SH, Park CW, Park JW, Kim DJ, et al. Basic techniques of intraoperative neurophysiological monitoring. Korean J Clin Lab Sci. 2013;45(2): 77-85.

10. Isu T, Kamada K, Mabuchi S, Kitaoka A, Ito T, Koiwa M, Abe H. Intra-operative monitoring by facial electromyographic responses during microvascular decompressive surgery for hemifacial spasm. Acta Neurochirurgica. 1996;138(1):19-23.

11. Stephen J, Haines, Torrs F. Intraoperative monitoring of the facial nerve during decompressive surgery for hemifacial spasm. Journal of Neurosurgery. 1991;74(2):254-257.

12. American Clinical Neurophysiology Society. Guideline 11B: Recommended standards for intraoperative monitoring of auditory evoked potentials [cited 2016 June 23]. Available from: https://www.acns.org/pdf/guidelines/Guideline-11B.pdf

13. Kim TJ, Ko Y, Kim YS, Oh SH, Kim KM, Kim NK, et al. Significance of intraoperative BAEPs monitoring during microvascular decompression surgery. J Korean Neurosurg Soc. 2000; 29:635-639.

14. Hanakita J, Kondo A. Serious complications of microvascular decompression operations for trigeminal neuralgia and hemifacial spasm. Neurosurgery. 1998;22(2) 348-352.

15. Iwakuma T, Matsumoto A, Nakamura N. Hemifacial spasm: comparison of three different operative procedures in 110 patients. J Neurosurg. 1982;57(6):753-756.

16. Joo BK, Park SK, Cho KR, Kong DS, Seo DW, Park K. Real-time intraoperative monitoring of brainstem auditory evoked potentials during microvascular decompression for hemifacial spasm. J Neurosurg. 2016:1-7.

17. Husain AM. A practical approach to neurophysiologic intraoperative monitoring. 1st ed. New York: Demos; 2014. p90-91. 